13. Savchenko, O.Ya. (2002). Dydaktyka pochatkovoi shkoly [Didactics of primary school] : pidruch. Kyiv : Heneza. 368 p. [in Ukrainian].

14. Sysoieva, S.O. (2011). Interaktyvni tekhnolohii navchannia doroslykh [Interactive technologies of adult learning] : navch.metod. posib. Kyiv : VD "EKMO". 324 p. [in Ukrainian].

15. Sysoieva, S.O. (2006). Pedahohichni tekhnolohii: korotka kharakterystyka sutnisnykh oznak [Pedagogical technologies: a brief description of the essential features]. Pedahohichnyi protses: teoriia i praktyka. Vyp. 2. P. 127-131 [in Ukrainian].

16. Skrypnyk, M.I. (2005). Interaktyvne navchannia: osnovni poniattia [Interactive learning: basic concepts]. Ihry doroslykh. Interaktyvni metody navchannia. Kyiv : Red. zahalnoped. haz. P. 30-44 [in Ukrainian].

DOI https://doi.org/10.51647/kelm.2020.4.1.3

\title{
TECHNOLOGY OF FORMATION OF INNOVATIVE IDENTITY OF FUTURE TEACHERS OF MUSIC ART
}

\author{
Anzhelika Bondarenko \\ Candidate of Pedagogical Sciences, \\ Senior Lecturer at the Department of Methods of Music Education, Singing and Choral Conducting \\ of the Faculty of Arts \\ Kryvyi Rih State Pedagogical University (Kryvyi Rih, Dnipropetrovsk region, Ukraine) \\ ORCID ID: 0000-0002-9068-9264
}

\begin{abstract}
The transition from the traditional to the innovative paradigm of teaching places the new demands to a teacher of music art in accordance with the models of a professional, worked out by a society. The understanding of the concepts of "innovation", "identity" made it possible to consider the essence of the teacher's innovative pedagogical activity. We have developed the concept of "pedagogically-innovative identity of the teacher of musical art" and specified the factors of the formation of the pedagogically-innovative identity. There have been specified the factors for the formation of the pedagogically innovative identity as an integrated quality of a teacher of music art. There have been analized the peculiarities of the innovative pedagogical technologies in music education. The content of the technology for the formation of the innovative identity of the future teachers of music art in the professional training process in the higher educational institution has been considered. The organization and the implementation of the coordinative influence defined by the certain educational methods, ways, and means. The expediency of using the didactic approaches in the process of the formation of the innovative identity of the future teachers of music. The stages for the realization of the pedagogical technology for the formation of the innovative identity of the future teachers of music art have been specified. An example of an instruction card to organize the individual academic activities with students has been presented. The author has provided the system of teaching methods, forms, means and ways, which includes three blocks.
\end{abstract}

Key words: innovative pedagogical technology, innovative identity, a teacher of music art.

\section{ТЕХНОЛОГІЯ ФОРМУВАННЯ ІННОВАЦІЙНОЇ ІДЕНТИЧНОСТІ МАЙБУТНІХ УЧИТЕЛІВ МУЗИЧНОГО МИСТЕЦТВА}

\author{
Анжеліка Бондаренко \\ кандидат педагогічних наук, \\ старший викладач кафедри методики музичного виховання, співу та хорового диригування \\ факультету мистецтв \\ Криворізького державного педагогічного університету \\ (Кривий Ріг, Дніпропетровська область, Украӥна) \\ ORCID ID: 0000-0002-9068-9264
}

\begin{abstract}
Анотація. Перехід від традиційної до інноваційної парадигми навчання висуває нові вимоги до вчителя музичного мистецтва відповідно до вироблених суспільством моделей професіонала. Фахова підготовка майбутніх учителів музичного мистецтва у процесі навчання у вищому навчальному закладі передбачає формування знань і вмінь щодо музично-естетичного розвитку учнів, а також набуття особистого досвіду творчого самовиявлення у музично-педагогічній діяльності. Розуміння понять «інновації», «ідентичність» уможливило здійснення розгляду сутності інноваційної педагогічної діяльності вчителя. Нами розроблено поняття «педагогічно-інноваційна ідентичність вчителя музичного мистецтва» та визначено фактори формування педагогічно-інноваційної ідентичності. Розгляд понять «технологія навчання», «педагогічна технологія», «інноваційна педагогічна технологія» уможливив з'ясувати те, що сучасні педагогічні технології сприяють оптимізації професійної зорієнтованості студентів. Визначено фактори формування педагогічно-інноваційної ідентичності як інтегрованої якості
\end{abstract}


вчителя музичного мистецтва. Проаналізовано особливості інноваційних педагогічних технологій у музичній освіті. Розглянуто зміст технології формування інноваційної ідентичності майбутніх учителів музичного мистецтва під час фахового навчання у вищому навчальному педагогічному закладі. Педагогічне керівництво самостійною навчальною діяльністю студентів під час застосування технології формування інноваційної ідентичності передбачає організацію та здійснення координуючого впливу визначеними навчальними методами, способами, засобами. Використання педагогічної технології формування інноваційної ідентичності пов'язане із залученням студентів до самостійної навчальної діяльності під контролем викладача, що сприяє налагодженню комунікативних зв'язків із іншими суб'єктами, інтенсифікації пошуково-дослідницької діяльності, розвитку вмінь творчого опрацювання даних. Обгрунтовано доцільність використання дидактичних підходів до процесу формування інноваційної ідентичності майбутніх учителів музичного мистецтва, а саме: когнітивно-інформаційний; контекстний; дискретний; компетентісно-орієнтований; комунікативно-діяльнісний; рефлексивно-креативний. Визначено етапи реалізації педагогічної технології формування інноваційної ідентичності майбутніх учителів музичного мистецтва. Наведено зразок інструкційної карти для організації самостійної навчальної діяльності зі студентами. Представлено авторську систему навчальних методів, форм, засобів і способів, що передбачає три блоки.

Ключові слова: інноваційна педагогічна технологія, інноваційна ідентичність, учитель музичного мистецтва.

\title{
TECHNOLOGIA KSZTALTOWANIA INNOWACYJNEJ TOŻSAMOŚCI PRZYSZŁYCH NAUCZYCIELI SZTUKI MUZYCZNEJ
}

\author{
Anzhelika Bondarenko \\ kandydat nauk pedagogicznych, \\ starszy wykładowca Katedry Metodyki Wychowania Muzycznego, Śpiewu i Dyrygentury Chóralnej \\ Wydziatu Sztuki \\ Krzyworoskiego Państwowego Uniwersytetu Pedagogicznego \\ (Krzywy Róg, obwód dniepropietrowski, Ukraina) \\ ORCID ID: 0000-0002-9068-9264
}

\begin{abstract}
Adnotacja. Przejście od tradycyjnego do innowacyjnego paradygmatu nauczania stawia nowe wymagania nauczycielowi sztuki muzycznej zgodnie z opracowanymi przez społeczeństwo modelami zawodowcy. Szkolenie zawodowe przyszłych nauczycieli sztuki muzycznej w procesie podjęcia studiów w szkole wyższej obejmuje kształtowanie wiedzy i umiejętności w zakresie rozwoju muzycznego i estetycznego uczniów, a także nabycie osobistego doświadczenia twórczej ekspresji w działalności muzyczno-pedagogicznej. Zrozumienie pojęć ,innowacja”, „tożsamość” umożliwiło rozważenie istoty innowacyjnej działalności pedagogicznej nauczyciela. Opracowaliśmy pojęcie ,pedagogiczno-innowacyjna tożsamość nauczyciela sztuki muzycznej” i zidentyfikowaliśmy czynniki kształtujące tożsamość pedagogiczno-innowacyjną. Rozważenie pojęć „technologia nauczania”, „technologia pedagogiczna”, „innowacyjna technologia pedagogiczna” pozwoliło dowiedzieć się, że nowoczesne technologie pedagogiczne przyczyniają się do optymalizacji orientacji zawodowej uczniów. Zidentyfikowano czynniki kształtujące tożsamość pedagogiczno-innowacyjną jako zintegrowaną jakość nauczyciela sztuki muzycznej. Przeanalizowano cechy innowacyjnych technologii pedagogicznych w edukacji muzycznej. Omówiono treść technologii kształtowania innowacyjnej tożsamości przyszłych nauczycieli sztuki muzycznej podczas kształcenia zawodowego w wyższej szkole pedagogicznej. Pedagogiczne kierowanie samodzielną działalnością dydaktyczną uczniów przy zastosowaniu technologii kształtowania tożsamości innowacyjnej przewiduje organizację i realizację wpływu koordynacyjnego przez pewne edukacyjne metody, sposoby, środki dydaktyczne. Wykorzystanie pedagogicznej technologii kształtowania innowacyjnej tożsamości jest związane z zaangażowaniem uczniów w niezależne działania edukacyjne pod kontrolą nauczyciela, co sprzyja budowaniu komunikacji z innymi podmiotami, intensyfikacji działań poszukiwawczobadawczych, rozwoju umiejętności twórczego przetwarzania danych. Uzasadniono stosowanie dydaktycznych podejść do procesu kształtowania innowacyjnej tożsamości przyszłych nauczycieli sztuki muzycznej, a mianowicie: poznawczoinformacyjne; kontekstowe; dyskretne; zorientowane na kompetencje; komunikatywno-aktywne; refleksyjno-kreatywne. Określono etapy wdrażania technologii pedagogicznej kształtowania innowacyjnej tożsamości przyszłych nauczycieli sztuki muzycznej. Przedstawiono przykładową kartę instruktażową do organizowania samodzielnych zajęć edukacyjnych ze studentami. Przedstawiono autorski system metod, form, środków i sposobów nauczania, obejmujący trzy bloki.
\end{abstract}

Słowa kluczowe: innowacyjna technologia pedagogiczna, tożsamość innowacyjna, nauczyciel sztuki muzycznej.

Introduction. In the 21 st century, along with the acceleration of the pace of the scientific and technological progress, the possibility of the creative self-expression of the teachers of music art in the musical and pedagogical activity with the school-age students is increasing. In the context of the dynamics of the scientific and technological progress, music education in the preparation of future specialists in the field of musical art in a higher institution contributes to the formation of a certain level of musical culture, intellectual development, understanding of the essence of musical and aesthetic development of the young generation. It is important in the scientific progress to assist the students in: engaging in the research and development activities using the modern information technology; preparing for the innovative pedagogical activity; acquiring the ability to be oriented in the information area of the musical pedagogical science to acquire new knowledge, the educational and methodological material as to the organization of musical and aesthetic development of schoolchildren; the creative self-realization in the musical and pedagogical activity. In this process, the system of monitoring the functioning of the educational activity infrastructure is used. Of course, the quality of the professional training of the future teachers of music depends on the competence of teachers, the innovative orientation of their teaching activities. "The decisive role 
in the acquisition of the innovative technologies and methods by the teachers of the national universities can be implemented through their traineeship in the leading higher educational institutions abroad, as well as their participation in the process of the academic mobility" (Klyap, 2015: 51).

However, the study of the chosen problem involves the identification of a number of contradictions: a) between the increase in knowledge and unpreparedness of teachers to be oriented in the information flow, the usage of the modern computer technology and multimedia, the actions in the innovation environment and the innovations implementation; b) between the necessity for the professional training of future teachers of music for the innovative pedagogical activity and the lack of the appropriate content and methodological support.

The urgency of introducing the technology of the innovative identity formation of the future teachers of music art is conditioned by the formation of new paradigms of higher education in Ukraine.

The problems of the innovative paradigm of high school are studied by such researchers as A. Aleksyuk, I. Dobroskok, V. Kremen, V. Kotsur, S. Nikitchyna and others, who consider the humanistic strategy based on the co-evolution of a personality of a future professional and the innovative environment. There searchers V. Andreev, E. Hubansky, P. Koptyeryev, A. Tubelsky and others consider the problem of an individual's self-development.The process of selfdevelopment is identified with the education process and the self-improvement for the acquisition of knowledge and skills aimed to perform the certain social functions. The future teachers' professional training is aimed at training the highly qualified competitive specialists capable of the creative self-realization in music and pedagogical activity. The problem of identity has been studied by such scientists as V. Aheev, H. Andreeva, N. Antonov, D. Zavalyshyn, O. Yermolaev, N. Ivanov, E. Klimov, H. Markus, S. Straiker, D. Turner and others, who understand the identity of an individual both as a person and a subject in the educational environment. The role of the pedagogical technology in the structure of the educational process has been considered in the works of N. Abashkin, K. Bakhanov, V. Bondar, S. Honcharenko, O. Savchenko, T. Selevko, V. Korneeva, O. Pometun and others. The innovative pedagogical teaching technologies are considered as a set of the effective methods and techniques for using in the educational process. Despite the increased interest of the scientists in the problem of the development and introduction of the innovative pedagogical technologies in the educational process of professional training of future teachers of musical art in higher educational institutions, the study of the content of the pedagogical technology of the formation of the innovative identity of the future teachers of music art has not been performed yet.

Main part. In the era of information and computer technology, the professional training of future teachers of music is changing qualitatively. The requirements for a modern teacher of music are taken into account in the professional training of students, and a search is made for the ways to optimally use the resources of the educational process. The question is with whom and what the student who chooses the profession of a teacher of music identifies himself, and what tasks he or she is planing to solve during the self-development period.

Let's consider the concept of "innovation" in the pedagogical science, which involves the creative implementation of the theoretical concepts of education and teachinging systems, as well as the process of creating and implementing the new means of solving the pedagogical problems using the modern teaching methods, means, forms. According to the music and pedagogical context of innovations, the concept of "innovation" stated by D. Hvishiani as a complex process of creation, dissemination of a new practical tool for the new social needs, as well as a process of combining changes in the social environment where its life cycle takes place, is considered to be an appropriate one (Gvishiani, 2007: 172).

The innovative pedagogical activity of a teacher in a higher educational institution becomes a factor and a cause for the formation of the innovative identity of students. It is advisable to consider the essence of the concept of "identity". The researchers understand this concept as a conscious sense of an individual of their own uniqueness, and its integrative property contributes to the desire to combine with the ideals of a certain group of individuals under the conditions of its correspondence (Ericson, 1996: 339). It is determined that a professional identity is a type of a social identity. Based on this, we understand identity as a system of the individual resources of a person. Educating the conscious identity of a future music teacher allows to develop a system of values and beliefs as to the ideal professional image and promotes the adaptation of an individual to the conditions of musical and pedagogical activity. The markers of an identity for a future music teacher are: innovative culture; communication; emotional stability; endurance; tact; ability to define a point of view; ability to express thoughts clearly; creativity; development of music and pedagogical skills; creative self-realization; self-presentation.

The formed innovative identity of a music teacher can be represented as follows: 1. Educational experience of an individual. 2. Experience of music and aesthetic perception. 3. Communicative experience in an innovative environment. 4. Experience in the organization of the educational work of students using a computer, online resources, music computer programs. 5. Music performance experience. 6. Experience of music and creative activity. 7. Experience of reflective activity.

Considering the process of forming the innovative identity of future music teachers, we have taken into account the fact that the development of an individual personality occurs starting from the professional training in a higher educational institution as well as during the creative self-realization in the musical and pedagogical activity with the use of the innovative pedagogical technologies. The important thing in the process of the professional training is to develop the students' need to constantly improve themselves and to quickly form their readiness for the professional activity in the modern conditions. The formation of the latter involves encouraging the students to identify an innovative music art teacher capable of self-regulation, self-control, self-organization, self-actualization, self-realization, selfprediction. The students should be aware that the effectiveness of their music and pedagogical activity depends on their own creative activity, their individual level of development, their willingness to work in the innovative processes. 
The above stated allows to introduce into the scientific circulation the concept of the "pedagogically innovative identity of a teacher of music", which appears as an awareness of an individual as an innovative teacher to adopt the standards of the innovative pedagogical activity, the values and behaviors, personal qualitative characteristics. The use of this category is characterized by the definite peculiarities related to multimedia and multimedia environment, the creative understanding by an individual of the innovative pedagogical technologies. The pedagogical innovative identity at each of the stages of the formation and self-improvement of the innovative teacher of music art provides the intensity of the professional development, in particular, the satisfaction of music and creative needs by means of the innovative pedagogical technologies. It should be mentioned that the teacher of music art shows the creative potential when factors operate effectively in the general system of "teacher - innovative environment - students". Considering this, pedagogical and innovative identity reflects the presence of knowledge as to the use of the innovative pedagogical technologies, the level of the pedagogical culture of a teacher of music art, his or her experience for the creative selfexpression in musical and pedagogical activity. The pedagogical innovative identity specifies the creative actions of a teacher of music art, the attitude to the organization of the process of music and aesthetic development of students. It embodies both the traditional foundations of the pedagogical ethics and the contemporary understanding of a teacher's personality as a mentor and a consaltant.

The formation of a pedagogically innovative identity as an integrated quality of a teacher of music art is determined by many factors: an individual's orientation to the creative self-development, professional competence, readiness for the communicative interaction with other subjects of the innovative environment. In such circumstances, in its subject code there is always an ideal image that specifies the innovative teacher of musical art of the 21 st century by the understanding of the harmonious combination of the rational and emotional behaviour, taking into account the thinking of the contemporary schoolchildren, their educational needs and interests. The process of the formation of the pedagogically innovative identity involves a purposeful influence on the development of the moral, intellectual and emotional spheres of an individual. Each future teacher of music art, while studying at a higher education institution, together with the acquisition of the professional competencies, gradually acquires the beliefs, which in music and pedagogical activity will contribute to the development of their own pedagogical style according to a certain ideal image.

The consideration of the process of the formation of the pedagogically innovative identity of the future teacher of music art requires understanding of the concept of "teaching technology". It is known that the concept of "technology" (Greek techne - art, skills; logos - word, doctrine) has arisen in the connection with the technological progress. Teachrning technologies are characterized by a clear sequence of operations with the use of the certain means with a view to a specific result (Lozova, 2002: 400). On this basis, we consider the concept of "pedagogical technology". It should be said that the researchers consider this concept as a direction in the pedagogical science, as well as the analysis of the features of the pedagogical technology, the means of optimizing the educational process in the system of the actions of a teacher and students, which are to be planned. We prefer the definition made by L. Kryvshenko, who considers this concept as "a clear scientific design and an accurate reflection of the pedagogical actions providing the success" (Krivshenko, 2004: 318).

We believe that pedagogical technology involves the selection of teaching methods, tools and forms aimed at the effectiveness of the educational process. Today, researchers have developed and implemented in the educational process of the professional training of students of the higher educational institutions such pedagogical technologies as: information teaching technologies using the information and communication means, the technology of the differentiated teaching, a game technology, a personality-oriented technology, a designing technology, a creative development technology, a dialog-form technology, a module technology, a problem learning technology and etc. Figure 1 shows the landscape of innovative pedagogical technologies in music education.

Due to the pressing challenges which face the field of music education, a new incentive for the innovations has emerged: the demand for the innovative pedagogical technologies that help to solve teaching problems. The innovative pedagogical technologies provide the combined paper and electronic forms, which are taken into account in the educational process of a higher education institution for the inclusion in the corresponding educational programs for the purpose of optimizing, modeling of the process of the preparation of the future teachers of music art for music and pedagogical activity. It should be noted that the level of development of modern computer technology makes it possible to use the modern management concepts in the music education.

The innovative pedagogical technologies in music education are the methods, means of the innovative activity of the teacher of music art with the usage of multimedia and information environment, aimed at the theoretical and practical elaboration by the students of the innovations in music education, the implementation of students' initiatives that change the level of students' development. In addition, the innovative pedagogical technologies are connected with the ethics of music and pedagogical work, the principles of music and aesthetic development of the schoolage students. The generalization of the researchers' opinions as to the innovative pedagogical technologies in music education provides the grounds for such a classification of the innovations for the professional training of the future music teachers: the invention of the new innovative pedagogical technologies; the adaptation of the new innovative pedagogical technologies to the modern conditions of the professional education of the students in a higher educational institution; the technological transfer from other spheres taking into account the peculiarities of music and aesthetic development of the students of the secondary schools, the extra-curricular educational institutions.

It should be noted that the innovative pedagogical technologies in music education are conditionally divided into those that are strategic in terms of preparing future professionals to perform music and pedagogical activities, and those aimed at increasing their individual level of music and pedagogical development. The first group includes 
the innovative pedagogical technologies of the tactic orientation, which are focused on providing the conditions of education for the teacher of music art close to the conditions of future professional activity, the acquisition of professional competencies by the students. The second group consists of the innovative pedagogical technologies aimed at providing future teachers of music arts with the necessary professional knowledge for the practical elaboration of the educational tasks as to the music and aesthetic development of the school-age students. The combination of these groups contributes to the successful achievement of the goals set for the professional training of future music teachers. For example, in order to overcome the problem of the students' creative self-expression during the professional training, it will be insufficient to develop and implement the innovative pedagogical technologies aimed at developing students' creative abilities and skills in the educational process. In practice, it is important to develop and implement the effective pedagogical technologies that will focus on the future music and pedagogical activities, working out the problem teaching situations, methodically preparing students to use the structural components of the heuristic learning, modern computer technologies.

Based on the above stated, we will consider the content of the pedagogical technology for the formation of the innovative identity of future teachers of music. This is an innovative resource-oriented technology for teaching future teachers of music art aimed at an inquiry-oriented searching and researching activities, and provides students with a set of the consistent interrelated tasks to form an innovative identity for mastering the skills of solving the problems, analysing the information, defining problems, engaging with other subjects to elaborate a creative product. This technology allows to monitor the level of students' mastery of the modern computer technologies, to check the level of the development of the intellectual skills without humiliating the dignity of students. The flexible organizational structure of the technology involves the engaging of the students into the independent teaching activities under the control of the teacher, and aims at developing the communication links between the subjects to ensure the effective interaction, and is focused on timely adaptation of the future music teachers to the changes in the information environment. The qualitative result of the use of the pedagogical technology of the formation of the innovative identity of future teachers of music art depends on the professional and methodological level of the teacher. This technology involves the sequence of actions of the teacher, which organizes students' independent learning activities, taking into account their knowledge of multimedia, modern computer technologies, the level of their musical and pedagogical development. The teacher sets the parameters for the students' independent learning activity with the definition of the time limits. The teacher's evaluation of the results of the independent learning activity is performed based on the following main criteria: use of Internet resources; communication skills; use of professional knowledge; creative approach; the result of independent learning activities.

The organization of the independent educational and cognitive activities of future music teachers is carried out using the forms of advisory support from the teacher, as well as using the various forms of training, such as educational games, creative activity, the use of formal assessment, cognitive and searching activities. Engaging the students in a group-based learning is based on a competency-oriented approach, and involves establishing "subject - subject" relationships in the certain groups where each individual is a developing technologist for himself / herself by enhancing his or her individual level of the development during the self-learning activity, as well as for other subjects of training in the process of the problem-seeking training activities. This form assumes the use of the common intellectual potential of the resources, taking into account the need to maintain the feedback between the participants of this communication act. Considering that the preparation of the future music teachers to collaborate in an innovative environment with other creative individuals implies encouraging them to master the interpersonal skills, it is appropriate to use a form of Peer learning, that involves developing the students' ability to evaluate their learning skills. We have taken into account that Peer training and Self-learning are considered to be "information and telecommunication technologies in education that involve the use of the specialized technical information tools" (Encyclopedia of Education, 2008: 364).

The development of the pedagogical technology for the formation of the innovative identity of future teachers of music art involved the definition of the didactic approaches that allow to reflect the ideas, concepts, prescriptions that determine the nature of the consideration of the chosen problem, namely: cognitive-information; contextual; discrete; competence-oriented; communicative activity; reflective-creative. The cognitive-information approach defines the purpose of the process for the formation of the innovative identity of future music teachers, as the creation of the conditions for cognition, accumulation and exchange of knowledge for further combining, unification, transformation, modeling of data. The contextual approach involves taking into account in the formation of innovative identity of future music teachers not only the system of knowledge and skills, but also the model of a specialist, which represents the peculiarities of music and pedagogical activity of the teacher of music art. The discrete approach (Sharshov, 2006: 20) involves the achievement of phenomena related to self-development of an individual during the formation of the innovative identity, namely: self-organization, self-knowledge, selfdevelopment, self-realization. The competence-oriented approach envisages the formation of the key competences of the future music teachers to pursue the innovative music and pedagogical activities. The communicative activity approach to the formation of the innovative identity of the future teachers of music arts provides the awareness of the communicative function of a teacher, the importance of the ability to communicate appropriately to the use of the information environment, media. At the same time, the activity of the future music teachers is directed at their self-development and contributes to the productive increase of their level of the individual music and pedagogical development. A reflective-creative approach involves engaging the persons in the process of reflection to seek the additional opportunities for the creative self-realization in the music and pedagogical activity. The combination 
of a student's positions in the role of "a student" and "an innovative teacher" determines the need for such an organization of the independent learning activities in a multimedia environment, which allows to provide the important indicators of his formation as an innovative teacher.

The technology for the formation of the innovative identity of the future music teachers is implemented in the following stages: 1. Review of Internet resources. The teacher sends to the students a recommended list of links to the online resources as an instruction card. 2. Identification of a problem. It is important to encourage the students to independently identify the problem of increasing the level of the individual musical and pedagogical development. Choosing the ways to achieve the goal to solve the problem involves the following: Internet resources to analyze the experience of music teachers; opportunities for students' musical and aesthetic development using multimedia, state-of-the-art music computer technology, innovative teaching methods and forms. The focus on the creative self-development of future music teachers implies the problem of developing their ability to express themselves creatively in music and pedagogical activity. At this stage, students draw up a technological map as a detailed description of the process of the independent learning activity for a specific learning task with a stepby-step presentation of the sequence of actions. 3. Choosing a form of the individual educational activity. Based on the fact that the individual learning activity under the supervision of a teacher can be carried out both in the classroom and outside the classroom with the help of the distance learning, at this stage it is important to work out the communicative situations with the students that can arise during the communication interaction in the distance form. The students independently distribute functions among themselves, process different sources of the authentic information. 4. Searching extra information. The students begin to search the information according to the assigned educational tasks, which involves the queries in the different sources, the educational work with a large amount of information. In this process, students acquire the ability to use the information resources in a practical way. Such educational work involves the identification of the information culture by the future music teachers. 5. The analysis of the possibilities of multimedia. The students coordinate the information flow independently, and for this purpose they master the multimedia tools, learn to perform the special commands, use the possibilities of a sound, video, animation, graphics, text. This requires to consider the types of activities into which the students are involved at the music lessons, as well as the ability to use the multichannel information. 6. The work with the state-of-the-art computer technologies. The students independently select one or more computer technologies to use their abilities in the individual learning activities. The persons search for the new connections between the certain objects. Working with the computer technology involves using a computer to work with data in the form of audio, video, animation, graphics, text. Working with the educational software allows the students to get acquainted with the ways of the educational work with the data using the communication and information abilities of the computer networks. 7. The discussion of the progress of research activities in a chat. The organization of discussion of the results of the collective intellectual activity involves identifying the drawbacks, carrying out a critical analysis of the individual learning activities, self-assessment, summarizing the data obtained, making the conclusions. 8. The presentation of the results of the idividual learning activity. This is performed on the server of the educational institution or on the website created.

The theoretical model of the pedagogical technology for the formation of the innovative identity of the future music teachers contains three interconnected blocks of the educational innovative methods and techniques. We have used such effective techniques of learning as creating the situations of success, the mutual assistance, the motivation to find the alternative solutions, the comparisons, the analogies, the methods of the polymodal representation of the aesthetic information, the associative memorization of an information, the reflective techniques, the heuristic techniques. This technology contains a set of teaching methods aimed at a holistic approach to the organization of the independent teaching activities of the future music teachers under the control of the teacher. We have taken into account the fact that the innovative teaching methods are a harmonious combination of the traditional learning and the creative searching results, using the original ideas and the forms to ensure the process of the professional preparation of the students.

The methods and techniques of the first block are aimed at activating the intellectual and willed spheres of the students to carry out the independent educational activity under the control of the teacher. This block provides the students' intellectual sphere to be set up for a productive entry into an innovative environment. The contextual essence of these methods involves setting the individual to the active research activity during the independent work in the distance form under the supervision of the teacher. Let us reveal the consistent essence of the teaching methods of this block, namely: the method for systematizing the knowledge; the method of the individual assistance; the method of the new situations; the method of the intensification of searching actions; the Model Orientation method; the method of the differentiated influence; the method of focusing on the individual success; the chain enrichment method; the non-verbal communication method; the method of anticipation.

Let's consider the essence of some of these methods. It is important that the information exchange in an innovative environment had an interactive behaviour. The chain enrichment method is aimed at attracting as many participants as possible to solve a problematic issue. Persons who are the experienced music teachers and who will become the active participants in the interactive activities together with students are invited to the team "Experienced". The teacher, as the organizer of the process of the formation of the innovative identity, engages the students in the "Active Assistants" team, and gives the task for the "Experienced" team members to work out a problematic issue. For example, in the vocal-choral work at the music art lessons with the school-age students, it is important to develop their auditory thinking through a music and to engage students in the use of a fantasy, imagination. 
The organizing teacher poses a problematic task for the development of an auditory thinking of schoolchildren and proposes to use the music computer programs: MIDI constructor "Techno Maker", "Magix Music Maker", Audio constructor "Dance eJaj", "Musicshake". These programs contain templates that allow students to create music themselves. The participants of the team of "Experienced" demonstrate the result of the collective intellectual activity to solve this issue. The students, as the members of the "Active Assistants" team, enrich the data they received. As a result, the team produces the educational and methodological developments that are practically tested with the school-age students.

We note that the participants of the interactive interaction in a multimedia environment are involved in the nonverbal communication. The signs and symbols allow not only a quick exchange of thoughts, but also an emotional attitude to a particular object. The "Non-verbal communication" method enables an individual to gain a personal experience of the communication with other subjects of the innovative environment using the signs and symbols. According to this method, the participants gradually develop their sign-symbolic toolkit, which facilitates the evaluation of a particular object, involving another subject in the dialogue, an invitation for a discussion.

Entering an individual into an innovative environment involves using the tools of multimedia, a computer technology. The teacher organizes students' analytical work when searching the educational topics on Internet sites and using hyperlinks of the specific pages. Of course, there are also problematic situations in this process. The method of anticipation contributes to the prediction, the determination of the patterns that contribute to the productivity of the innovative pedagogical activity of a teacher of music. The teacher engages the subjects of the interactive interaction in the collective study of the problem question, analysis and decision making. Such collective activity in the virtual space with the help of the computer technology ZOOM promotes the stimulation of the analytical thinking, facilitates the production of the ideas, promotes the development of the communication skills. It is advisable in this process to use the capabilities of a cloud technology, where services are provided from one provider on a single platform in the different directions at the same time.

The methods of the second block are aimed at developing the practical skills of the future music teachers in the development of the innovative pedagogical technologies, developing the ability to apply them in the musicpedagogical activity with schoolchildren, encouraging active and purposeful intellectual-creative activity using a computer. Let's reveal the consistent essence of the methods of the second block: the method of qualitative data conversion; the method of the emotional saturation; the "Leader" method; the creative searching method; the "Express Solution" method; the sequential actions method; the "Relay" method; the step by step method; the method of the practical orientation; the method of work at the thematic blocks.

It should be noted that the music teachers use music pieces as a supplement to a specific curriculum to engage the students in the music and pedagogical activity. The latter requires the music art teacher to prepare the students for the rehearsals. Taking into account the age peculiarities of the students, the possibilities of their vocal voices with the observance of the hygiene of the voice, etc., the music art teacher selects the musical repertoire and plans the systematic vocal and choral work with the students. Through the step-by-step method, the experienced teachers are able to demonstrate the results of the vocal-choral work with the students.

The subtitles to the video show the assigned educational task and the fragments of the vocal-choral work with the students, conducted by the teacher of the musical art for a certain period are shown. To create a list of songs that will be included in the repertoire of a vocal or choral ensemble, the change of the tone of a piece of music, the record of the sound of the vocal voices of the students, the creation of the video files for the educational purposes, it is advisable to use the means of such computer programs as: "Karaoke GALAXY", "Kar Maker", "Vocal Jam", and etc. As a result of the created video set, other persons have the opportunity to analyze the data, to get an advice from the experienced music teachers, to acquire the methodological knowledge.

In the process of the innovative identity of the future music teachers, it is important to encourage them to undertake the independent learning activities under the supervision of the teacher. The method of the practical orientation provides involving the students to work independently at watching video lectures with subtitles, which discuss problems of the innovative activity of the teacher of music art, the options for solving the problematic situations, and ICT-support of the music art lessons. At the end of each video lecture, it is obligatory to pass a test, the results of which testify the level of mastery of each student's knowledge and practical skills.

It is known that every teacher plans his music and pedagogical activity not spontaneously, but in the system of the musical-aesthetic development of the students. That is why many methods and forms of training using computer technologies, multimedia environment capabilities and multimedia tools have been developed today. The method of the work on the thematic blocks is aimed at acquiring the ability of a person to develop thematic blocks, which involves: combining several educational topics, the integration with other school disciplines, the use of works of art for the educational purposes, the systematic activation of students' interest during the extra-curricular activities. This training method involves the setting of the communicative tasks, namely: activation of partners during independent learning activities in the distance form, regulation of the process of data exchange. The use of the Google classroom computer technology makes it possible to create a personalized training course for the school-age students. The capabilities of this technology make it possible to place a specific subject block and to join students to this author's training course. The computer technology Learning Apps. org allows the use of the ready-made game training tasks by including them in the thematic block. At the same time, the computer technology On Line Test Pad is a good idea for creating the logical games for the students to learn music concepts and terms effectively. The peculiarity of the collective interactive activity of the participants of the independent educational work in the distance form is 
the joint completion of the file "Database", but during processing this data each person carries out independently creating the final product in the form of a thematic block for the students of a certain school age.

The methods of the third block contribute to the fixation by an individual the results of the independent intellectualcreative activity. With the help of these educational methods, the person analyzes the results of search and research activities, inaccuracies in the choice of objects revealed, the lack of certain data and self-control, self-analysis are used. The latter is the basis for the objective self-assessment, which will encourage the individual to understand the relationship between intensity and performance. Let's reveal the consistent essence of the educational methods of the third block: the method of intensive self-development; the method of joint progression; the method of creative self-government; the method of active cooperation; the free choice method; the method of the collective creative activity; the method of the creative combination of data; the method of interactive exchange of music material; the method of "Information environment +"; the method of "Teacher-facilitator".

Providing that there are many currents, subcultures, genres, and styles of music today, it is important for the teacher of musical art not only the use of music listened to the school-age children, but also for the development of the educational tasks of different educational orientation. The method of the interactive exchange of the music material is aimed at enriching the subjects of the innovative environment with the musical works, the fragments of musical works, the ways of using them in the various forms of the educational activity with the students at the lessons of music art. It is advisable to use the computer programs such as Windows Media Player, Win Amp, which contain a large amount of information and an organized data searching system. The received data can also be stored on Google Drive. This interactive exchange also involves the sharing of interactive ways of the creative processing of data with the use of multimedia tools, when using multichannel effects on the students or enhancing audio or visual channels.

The "Information Environment +" method involves the involvement of the participants in an independent learning activity in the distance form under the supervision of the teacher in the communicative interaction during the acquisition of knowledge and exchange of ideas. This teaching method promotes the acquisition by an individual the ability to organize the quests as mini-projects aim to involve students in finding data to solve a learning task. A music teacher must be able to involve the students in finding and arranging information, and the fragments of music will help students gain the aesthetic enjoyment. The problem setting involves incorporating the elements of a role-playing game using multimedia capabilities. According to this teaching method, future music teachers will learn how to set up a didactic task in accordance with a game plan and set clear rules.

In organizing the extracurricular students' activities, the innovative music teacher also uses the distance teaching to ensure the systematic musical and aesthetic development of the students. In order to involve the future teachers of music art in mastering the ways of using the distance form in the music and pedagogical activity with students, it is advisable to use the educational method "Educator-facilitator". This teaching method involves providing the organizing by a teacher of the information environment with the opportunity for students to acquire the skills for using: softonic computer technology, which allows to organize the short videos for the educational purposes; computer program Learning Apps. org, as well as using the Blank Quiz structural component, which makes it possible to create a questionnaire or a test, and transfer it to students to the further processing the data obtained; computer technology for creating educational slides at www.png; Word Art computer technology to create a mental map; Google Classroom computer technology to create the interactive, self-learning environments for students.

To solve the tasks and achieve our goal, we used a set of research methods, namely: theoretical: analysis of scientific and methodological literature, systematization of theoretical provisions, the method of pedagogical experiment.

Carrying out a contextual analysis of the technology of the formation of the innovative identity of the future teachers of music art provided the consideration of the theoretical bases of the use of this technology on the basis of the understanding of the concepts "innovation", "innovative pedagogical activity". The problem we chose required the understanding of the concept of "identity". We have identified the identity markers of a future music teacher, and on this basis defined the concept of the "pedagogically innovative identity of a teacher of music", and determined the factors of the formation of the innovative identity of a future music teacher. The analysis of the concepts "technology", "pedagogical technology", "innovative pedagogical technology" made it possible to justify the need to expand the modern idea of the innovative activity of the high school teachers, and to outline the possibilities of training future teachers of music art for the innovative music and pedagogical activity. The students' experience of using the innovative pedagogical technologies is formed within the artistic mentality. The development of this technology involved taking into account such didactic approaches as: cognitive-information; contextual; discrete; competence-oriented; communicative activity; reflexive-creative.

Conclusion. The formation of the innovative identity is directly dependent on the involvement of the students in the use of multimedia environment, multimedia facilities, modern computer technologies. In the process of understanding the category of the innovative identity of the future teacher of music art, as a complex, the integrative quality of the professional-pedagogical structure of an individual, the content of a certain pedagogical technology include the developed and presented author's methods, taking into account the effective ways, means and forms of teaching. The further scientific research requires the question of the substantiation of the effectiveness for introducing the technology of the formation of the innovative identity of future teachers of music art in the educational process.

\section{Bibliography:}

1. Гвишиани Д.М. Избранные труды по философии, социологии и системному анализу. Москва : Канон+, 2007. 672 с. DOI: 5-88373-193-7.

2. Енциклопедія освіти / за ред. В.Г. Кремінь. Київ : Юрінком Інтер, 2008. 1040 с. DOI: 978-966-667-281-3.

3. Эриксон Э. Идентичность: юность и кризис. Москва : Прогресс, 1996. 339 с. DOI: 5-01-004479-х. 
4. Кляп М. Інноваційні методи навчання у ВНЗ як інструмент інтернаціоналізації вищої освіти України. Buщза освіта України. 2015. Вип. 4. С. 51-53. DOI: 2078-1016.

5. Лозова B.I., Троцко Г.В. Теоретичні основи навчання і виховання. Харків : ОВС, 2002. 400 c. DOI: 966-7858-11-1.

6. Шаршов И.А. Педагогические условия профессионально-творческого саморазвития личности студента : дис. ... канд. пед. наук : 13.00. 01 / Белгор. гос. пед. ин-т. Белгород, 2000. 212 с. DOI: 2074-1774.

\title{
References:
}

1. Gvishiani D.M. (2007) Izbrannye trudy po filosofii, sociologii i sistemnomu analizu. [Selected works on philosophy, sociology and systems analysis]. Moskva : Kanon+, 672 s. DOI: 5-88373-193-7. [in Russian].

2. Entsyklopediia osvity (2008) [Encyclopedia of Education] / za red. V.H. Kremin. Kyiv : Yurinkom Inter, 2008.1040 s. DOI: 978-966-667-281-3. [in Ukrainian].

3. Erikson E. (1996) Identichnostь: iunostь i krizis. [Identity: youth and crisis]. Moskva : Progress, 339 s. DOI: 5-01-004479-x. [in Russian].

4. Kliap M. (2015) Innovatsiini metody navchannia u VNZ yak instrument internatsionalizatsii vyshchoi osvity Ukrainy. [Innovative methods of studying in the higher education institutes as an instrument for internationalization of vocal education of Ukraine]. Vyshcha osvita Ukrainy, issue 4. S. 45-53. DOI: 2078-1016. [in Ukrainian].

5. Lozova V.I., Trotsko G.V. (2002) Teoretychni osnovy navchannia i vykhovannia. [Theoretical foundations of education]. Kharkiv : OVS. 400 s. DOI: 966-7858-11-1. [in Ukrainian].

6. Sharshov I.A. (2000) Pedagogicheskie usloviia professionalno-tvorcheskogo samorazvitiia studenta. [Methodological foundations of the study of the process of professionally creative self-development]. dis. ... kand. ped. nauk : $13.00 .01 /$ Belgor. gos. ped. in-t. Belgorod. 217 s. [in Russian].

DOI https://doi.org/10.51647/kelm.2020.4.1.4

\section{ПОЕТАПНА МЕТОДИКА ФОРМУВАННЯ ГОТОВНОСТІ МАЙБУТНІХ УЧИТЕЛІВ МУЗИЧНОГО МИСТЕЦТВА ДО ТВОРЧО-ІНТЕРПРЕТАЦЙНОЇ РОБОТИ ЗІ ШКІЛЬНИМИ КОЛЕКТИВАМИ}

\author{
Ван Хайлун \\ аспірант кафедри теорії та методики музичної освіти, хорового співу та диригування \\ факультету мистецтв імені Анатолія Авдієвського \\ Національного педагогічного університету імені М. П. Драгоманова (Київ, Украӥна)
}

ORCID ID: 0000-0002-7350-5566

\begin{abstract}
Анотація. У положеннях наукової статті автор розкриває особливості методики формування готовності майбутніх учителів музичного мистецтва до творчо-інтерпретаційної роботи зі шкільними колективами під час вивчення диригентсько-хорових дисциплін. Обгрунтовується значення творчо-інтерпретаційної роботи майбутніх учителів музичного мистецтва над навчальними творами для набуття вміння створювати інтерпретації музичних творів і набуття вмінь музично-педагогічної роботи із різними типами шкільних колективів. Структура готовності майбутніх учителів музичного мистецтва до творчо-інтерпретаційної роботи зі шкільними колективами охоплює: змістово-логічний, операційно-процесуальний, творчо-діяльнісний компоненти. Представлено поетапну методику, що включає етапи, а саме: організаційно-когнітивний, технолого-поглиблений, дослідницько-результативний. До методики включено спецкурс «Творчо-інтерпретаційна робота зі шкільними колективами». Ефективність введення формувальних методів за розробленими етапами підтверджена експериментально та доводить цілісність науково-методичної концепції формування готовності майбутніх учителів музичного мистецтва до творчо-інтерпретаційної роботи зі шкільними колективами.

Ключові слова: творчо-інтерпретаційна робота, майбутній учитель музичного мистецтва, методика.
\end{abstract}

\section{PHASED METHODOLOGY OF FORMATION OF READYNESS OF FUTURE TEACHERS OF MUSIC ART FOR CREATIVE INTERPRETIVE WORK WITH TEAM OF STUDENTS}

\author{
Wang Hailong \\ Postgraduate Student at the Department of Theory and Methods of Music Education, \\ Choral Singing and Conducting \\ of the Faculty of Arts named after Anatoly Avdievsky \\ National Pedagogical Dragomanov University (Kyiv, Ukraine) \\ ORCID ID: 0000-0002-7350-5566
}

\begin{abstract}
The article reveals the peculiarities of the methodology of forming the readiness of future teachers of music to creatively interpretative work with school groups during the study of conducting and choral disciplines. The importance
\end{abstract}

